Bose had a genius for designing delicate and sensitive apparatus for his physiological investigations, fertility in initiating new lines for observation and a clear style of setting out his experimental results and theoretical deductions. Nevertheless, by his resonant recorder and oscillating recorder he actually did for the first time record the delicate movements of leaves of Mimosa and Biophytum without distortion. $\mathrm{He}$ also devised apparatus for demonstrating the effect of sleep, air, food, drugs, excitation, impulse, ete., on plants. He also demonstrated an instantaneous record of growth and death. Thus, according to him, did the plant automatically record its own physiological life-history. In 1919, he announced that he had obtained in plants very definite mechanical and electrical response to wireless impulses, and claimed that the "perceptual range of the plant is inconceivably greater than ours: it not only perceives but also responds to the different rays of the vast æthereal spectrum". His high-magnification crescograph which magnified the growth of a plant ten million times was received with enthusiasm in England in 1919-20. Doubt had originally been cast on the crescograph really recording growth magnification, but after demonstrating his apparatus in University College, London, a letter appeared in The Times of May 4, 1920, over the signatures of some of the leading British men of science stating that "the growth of plant tissues is correctly recorded by this instrument and at a magnification of from one to ten million times".

Bose received the C.I.E. for his scientific work at the Delhi Durbar in 1902. In 1911 he was awarded the C.S.I., and in 1915 he retired from the chair in Presidency College as emeritus professor on full pay. In 1917 a knighthood was conferred upon him, and in 1920 he was elected a fellow of the Royal Society.

Comment on Bose's praiseworthy work in physics would be superfluous : but he would be a daring man who attempted any precise evaluation of Bose's work in plant physiology at this stage. His work was prolific and his publications voluminous. He published a large number of books, and the "Transactions of the Bose Research Institute" contain much of his own work and much carried out in collaboration with others. Most of this work has been received in silence, and has neither been confirmed nor openly refuted. In any event, never will it be truthfully said that Bose was not a potent stimulus to contemporary physiologists, especially at the height of his career. A leading physiologist once said that Bose's "more general conclusions will probably not attract so much attention as the new experimental methods he employed'. But the application of Bose's methods in experimental physiology by other investigators is still to come.

Of Bose, the man, nothing but the most gracious and kindest thoughts can be entertained. He was a great patriot and took a deep interest in Indian culture; and his wider interests are shown by his former membership of the International Committee on Intellectual Co-operation of the League of Nations. Sir Jagadis is survived by Lady Bose, who for many years was a source of encouragement to him.

\section{Dr. K. J. Saunders}

DR: Kenneth J. SAunders, whose death at the age of fifty-three years occurred at Eastbourne on November 22, was an orientalist and authority on the religions of Asia of no little distinction.

Dr. Saunders was educated at Clifton College and Emmanuel College, Cambridge, of which University he was a D.Litt. From 1909 until 1912 he was a lecturer of Trinity College, Kandy, and it was in this period, through his contact with the Buddbist monks of Ceylon, that he acquired an insight into the practical working of the Buddhist faith. This determined his line of approach to the comparative study of the religions of the East as 'ways of life', which he demonstrated most strikingly in his studies of similarities in the doctrines of Buddhism and the teachings of Christ. He was also strongly impressed by the influence of Buddhism in the spread of the culture of India and Ceylon to other countries in Asia. These views on the place of Buddhism in the life and culture of the East were strengthened by a period of residence in Burma, when work for the Y.M.C.A. brought him into intimate contact with native students; and they were confirmed and deepened by pilgrimages to Buddhist shrines and centres in other parts of Asia, especially China and Japan, which he visited after the Great War.

Dr. Saunders was later appointed to the chair of comparative religions in Berkeley University, California, which he held until 1935. In the two following years, he was engaged in lecturing on Asiatic history ; but a breakdown in health prevented him from taking up his duties on appointment to the recently founded Spalding chair for the study of comparative religions in the University of Oxford.

WE regret to announce the following deaths:

Dr. O. C. Bradley, principal of the Royal (Dick) Veterinary College, Edinburgh, since 1911, on November 21, aged sixty-five years.

Mr. Edward T. Browne, a governor of the Marine Biological Association of the United Kingdom and a generous benefactor to science, well known for his zoological work on medusæ, on December 10, aged seventy-two years.

Prof. J. Henderson, professor of natural history in the Colorado Museum, an authority on invertebrate palæontology, on November 4, aged seventy-two years.

The Rev. Walter Howchin, emeritus professor of geology in the University of Adelaide, aged ninetytwo years.

Prof. A. Hutchinson, O.B.E., F.R.S., formerly professor of mineralogy in the University of Cambridge, lately master of Pembroke College, on December 12, aged seventy-one years.

Prof. Hans Molisch, formerly professor of botany in the University of Prague, on December 8, aged eighty-one years.

Mr. George Philip, chairman of Messrs. George Philip and Son, Ltd., geographical publishers, and author of several valuable library atlases, on December 8 , aged sixty-seven years. 